\title{
Znaczenie czynników VEGF i VEGFR w klinicznej ocenie chorych na raka wątrobowokomórkowego
}

\author{
Włodzimierz Otto ${ }^{1}$, Maria Król' ${ }^{2}$ Ewa Wilczek ${ }^{3}$, Janusz Sierdziński ${ }^{4}$, \\ Magdalena Feliksbrot-Bratosiewicz ${ }^{2}$, Urszula Wilkowojska², Marek Krawczyk ${ }^{1}$
}

Cel badań. Czynnik VEGF jest jednym z najsilniej działających promotorów angiogenezy i wywiera wpływ na rozwój raka wątrobowokomórkowego (HCC). Celem pracy było ustalenie wzajemnych relacji pomiedzy krążącym i tkankowym czynnikiem VEGF, charakterystyką patomorfologiczną guza i oceną kliniczną stopnia zaawansowania nowotworu u chorych chirurgicznych leczonych na HCC.

Materiał i metoda. Badaniem objęto 146 chorych z HCC, zakwalifikowanych na podstawie oceny klinicznej do: resekcji wątroby (Grupa A, N = 53 chorych), transplantacji wątroby (Grupa B, N = 49) lub do leczenia paliatywnego (Grupa C, $\mathrm{N}=44$ ). Od badanych pobierano $2 \mathrm{ml}$ świeżej krwi dla oznaczenia liczby endotelialnych komórek progenitorowych o fenotypie CD34+,309+ (EPCS) oraz $8 \mathrm{ml} \mathrm{krwi} \mathrm{dla} \mathrm{oznaczenia} \mathrm{poziomu} \mathrm{koncentracji} \mathrm{VEGF} \mathrm{w} \mathrm{surowicy} \mathrm{badaniem} \mathrm{se-}$ rologicznym (ELISA). Wszystkie guzy oceniono histopatologiczne (wycinki lub biopsja celowana USG), pod względem budowy, stopnia dojrzałości, obecności naciekania mikrokrążenia. Barwienie na obecność w tkankach VEGF oraz VEGFR przeprowadzono techniką immunohistochemii z przeciwciałami anty-VEGF/VEGFR i analizą morfometryczną wyników (Dako Cytomation). Dane opracowano statystycznie, uznając wartości $p<0,05$ za znamienne.

Wyniki. Chorzy w grupach różnili się warientem budowy guzów (Chisq $=13,44 ; p<0,001$ ), obecnością naciekania mikrokrążenia (Chisq =9,43; $p<0,01$ ), lecz nie stopniem dojrzałości guzów (NS). Różnice stwierdzono w odsetku krążących EPCs (Chisq = 30,55; $p<0,001$ ) oraz średnim poziomie VEGF i VEGFR w tkance guzów (Chisq =9,67; $p<0,008$ ). Wariant budowy, stopień dojrzałości i naciekanie mikrokrążenia nie wpływał na różnice w odsetku EPCs oraz w poziomie koncentracji VEGF/VEGFR w surowicy i tkance.

Wnioski. Oznaczenie krążących EPCs oraz białka VEGF i VEGFR w tkance HCC świadczy o potencjale guza do angiogenezy i wskazuje na stopień zaawansowania raka. Tylko oznaczenie liczby krążących EPCs dostarcza informacji w okresie poprzedzającym decyzję o losach chorego. Oznaczenie czynników angiogenezy jest wartościowym uzupełnieniem klinicznej oceny chorych.

\section{Significance of VEGF and VEGFR factors for clinical evaluation of hepatocellular carcinoma patients}

Aim. VEGF factor is the most active promotor of angiogenesis that supports HCC development. This study aimed to evaluate the relationships between expression of circulating and tumour VEGF and VEGFR factors, tumour pathomorphologic characteristics and the clinical stage of tumour development in HCC patients receiving surgery.

Material and methods. The study reports on 146 patients that were qualified for liver resection (Group A, N=53), liver transplantation (Group B, N =49), and palliation (Group $C, N=44$ ), according to standard systems of clinical

\footnotetext{
${ }^{1}$ Katedra i Klinika Chirurgii Ogólnej, Transplantacyjnej i Wątroby

${ }^{2}$ Klinika Onkologii, Hematologii i Chorób Wewnętrznych,

${ }^{3}$ Zakład Patomorfologii,

${ }^{4}$ Zakład Informatyki Medycznej i Telemedycyny,

Centralny Szpital Kliniczny, Warszawski Uniwersytet Medyczny
}

Grant No. NN 403177940 Narodowego Centrum Nauki 
evaluation. The samples of $2 \mathrm{~mL}$ of venous blood was collected and immediately evaluated by flow cytometer for the endothelial progenitor cells enumeration (EPCs). The samples of $8 \mathrm{~mL}$ of venous blood was centrifuged for serum and the measurement of serum VEGF concentration by ELISA. The tissue samples of HCC were examined for tumour grading and architectural growth pattern, and for the expression of VGEF/VEGFR-2 by using anty-VEGF/anty-VEGFR antibodies for immunohistochemical staining. The factors expression was evaluated by morphometric analysis (DakoCitomation). The data were analysed statistically; $\mathrm{p}$-values $<0.05$ were considered as significant.

Results. Patients differed by the tumour architectural growth pattern (chi-squared $=13.44, p<0.001$ ), and tumour microvascular invasion (chi-squared $=9.43, p<0.01$ ), but not by the stage of tumour differentiation. They presented with significant differences in the rate of circulating EPCs (chi-squared $=30.55, p<0.001$ ), and the level of tumour VEGF/VEGFR concentration (chi-squared $=9.67, \mathrm{p}<0.008$ ). The tumour growth pattern, the maturity and microvascular invasion were not influenced by the rate of circulating EPCs and serum/tumour VEGF/VEGFR concentration.

Conclusions. The rate of circulating EPCs and the level of VEGF/VEGFR tumour tissue concentration corresponded to the tumour potential of angiogenesis and indicated the stage of tumour development. Only the enumeration of circulating EPCs provide useful information prior the treatment decision denoting angiogenesis factors may be beneficial in the course of patients' clinical evaluation.

NOWOTWORY Journal of Oncology 2015; 65, 5: 404-410

Słowa kluczowe: rak wątrobowokomórkowy, angiogeneza, białko VEGF, endotelialne komórki progenitorowe Key words: hepatocellular carcinoma, angiogenesis, VEGF protein, endothelial progenitor cells

\section{Wstęp}

Naczyniowo-śródbłonkowy czynnik wzrostu VEGF (Vascular Endothelial Growth Factor) jest jednym z najsilniej działających promotorów angiogenezy, uważanej za istotny proces w rozwoju raka wątrobowokomórkowego (HCC) [1, 2].

Dane przytaczane w licznych pracach wskazują, że wysoki poziom koncentracji VEGF obecny w surowicy krwi oraz $w$ tkance guza przemawia za intensywnym rozwojem nowotworu i jest złym czynnikiem prognostycznym [3, 4]. Nie brak jednak doświadczeń i obserwacji klinicznych negujących znaczenie czynnika VEGF w rozwoju HCC (hepatocellular carcinoma), a zwłaszcza jego roli w progresji nowotworowej $[5,6]$. Kontrowersje budzi także znaczenie badań aktywności VEGF w klinicznej ocenie chorych i podejmowaniu decyzji o sposobie ich leczenia [7-12].

W pracy przedstawione zostały wyniki badań poziomu expresji VEGF i jego receptora VEGFR-2 we krwi obwodowej i w tkance wyciętego raka wątrobowokomórkowego. Jej celem było ustalenie wzajemnych relacji pomiedzy krążącym i tkankowym czynnikiem VEGF, charakterystyką patomorfologiczną guza i oceną kliniczną stopnia zaawansowania nowotworu u chorych chirurgicznych leczonych na HCC.

\section{Materiał i metody}

Badaniem objęto łącznie 146 chorych na raka wątrobowokomórkowego. Każdy wyraził pisemną zgodę na udział w badaniu, zaaprobowanym przez Komisję Bioetyczną Warszawskiego Uniwersytetu Medycznego (Grant Narodowego Centrum Nauki, No. NN 403 177940/E154). Na podstawie stopnia zaawansowania klinicznego chorych z HCC zakwalifikowano do trzech grup postępowania:
- do resekcji wątroby - Grupa A - zaliczono 53 chorych (31 M, 22 K, średnia wieku 55 lat), u których rozpoznano guz w I stopniu zaawansowania klinicznego (T1, N0, M0, O-A1 wg oceny BCLC - Barcelona Clinic Liver Cancer), w okresie wydolności wątroby. U 29 guz rozwinął się w wątrobie zdrowej, u 24 w wątrobie marskiej po przebyciu wirusowego zapalenia wątroby HBV/HCV; u 9 z nich stwierdzono chorobę alkoholową (ALD). Poziom alfa-fetoproteiny $w$ surowicy krwi wynosił średnio $15,5 \mathrm{ng} / \mathrm{mL}$ (SD+/-1457), liczba płytek krwi $160 \times 109 / \mathrm{L}$ (SD+/-74000), INR 1,06 (SD+/-0,14);

- do transplantacji wątroby - Grupa B - zaliczono 49 chorych (34 M, 15 K, średnia wieku 50 lat), u których rozpoznano guz $\mathrm{w}$ Il stopniu zaawansowania klinicznego (T1/T2, N0, M0), pojedynczy guz $<5 \mathrm{~cm}$ lub 3 guzy o średnicy $<3 \mathrm{~cm}$, tj. spełniający „kryteria mediolańskie, A2-A4 wg oceny BCLC), w okresie wydolności wątroby (wątroba marska w grupie wydolności A/B wg Childe'a). U wszystkich przyczyną marskości było zakażenie wirusowe HBV/HCV; u 10 potwierdzono chorobę alkoholową. Poziom alfa-fetoproteiny wynosił średnio $43,35 \mathrm{ng} / \mathrm{mL}$ (SD+/-3444), liczba płytek krwi $75 \times 109 / \mathrm{L}$ (SD+/-46000), INR 1,13 (SD+/-0,13);

- do leczenia paliatywnego - Grupa C - zaliczono 44 chorych ( 24 M, 20 K, średnia wieku 61 lat), u których rozpoznano zaawansowanego raka w wątrobie zdrowej lub marskiej (stopień kliniczny III/IVB-C wg oceny BCLC). U 8 chorych guz rozwinął się w zdrowej wątrobie, u 34 w wątrobie marskiej w przebiegu zakażenia $\mathrm{HBV} / \mathrm{HCV}$; u 10 potwierdzono chorobę alkoholową. Poziom alfa-fetoproteiny u chorych wynosił średnio 
59,05 ng/ml, (SD+/-1748), liczba płytek krwi 123 × 109/L (SD+/-82000), INR 1,13 (SD+/-0,13).

W okresie poprzedzającym leczenie (1-3 dni przed operacją lub po decyzji o leczeniu paliatywnym) od chorych pobierano próbki krwi. Dla oznaczenia w badaniu cytometrycznym progenitorowych komórek endotelialnych pobierano $2 \mathrm{ml}$ krwi żylnej na odczynnik K3EDTA. Próbkę analizowano niezwłocznie, oznaczając odsetek komórek o fenotypie CD34+,309+,45+ i CD34+,309+,45-, zgodnie z procedurą wieloparametrycznego bramkowania aprobowanego przez International Society of Hematology and Graft Engineering (ISHAGE), opisanego szczegółowo w poprzednio raportach [13-15]. Wyniki podano jako sumę odsetka komórek o fenotypie CD309+ w subpopulacji komórek macierzystych CD34+.

$\mathrm{Na}$ badanie serologiczne poziomu koncentracji VEGF w surowicy krwi pobierano $8 \mathrm{ml}$ krwi, z której surowicę, po odwirowaniu próbki z szybkością 3000 obrotów/minutę przez okres 10 minut, składowano w temperaturze $-80^{\circ} \mathrm{C}$. Koncentrację VEGF oznaczano za pomocą testu immunoenzymatycznego (Quantikine Human VEGF Immunoassay, R\&D Systems, Minneapolis, MN, USA); $100 \mu$ l standardu rekombinowanego ludzkiego czynnika VEGF łączono z próbką badanej surowicy, rozcieńczano, nanoszono na płytkę pokrytą mysim monoklonalnym przeciwciałem specyficznym dla VEGF i inkubowano przez 2 godziny w temperaturze pokojowej. Po spłukaniu do próbki dodawano peroksydazę chrzanową i poliklonalne przeciwciało specyficzne dla VEGF i po kolejnym spłukaniu - 3,3'5,5' substrat tetrametylobenzudyny (TNB). Czułość metody wynosiła 9 pg/ml, a współczynnik precyzji badania i pomiędzy badaniami wynosił 4,4-6,7\% i 6,2-8,8\%.

Histopatologicznie zbadano 102 guzy wycięte operacyjnie i 44 wycinki pobrane podczas biopsji gruboigłowych u chorych leczonych paliatywnie. Preparaty utrwalono w 10-procentowej formalinie i zatopiono w parafinie. Bloczki tkanki skarawano na sekcje grubości $4 \mu \mathrm{m}$, wybarwiano hematoksyliną/eozyną. Oceniono stopień zróżnicowania guza wg skali Edmondsona-Steinera, wariant budowy (beleczkowy, pseudogruczołowy, lity) i obecność naciekania przez nowotwór mikrokrążenia.

Barwienie tkanek na obecność VEGF oraz VEGFR przeprowadzono techniką immunohistochemii, stosując przeciwciała anty-VEGForaz anty-EGFR (Dako Cytomation) i zestaw przeciwciał drugorzędowych sprzężonych z cząsteczkami peroksydazy chrzanowej ImmPress Anty-Mouse-HRP Detection Kit (Vector Laboratories). Barwienia przeprowadzono w autostainerze Leica Bond-MAX (Leica). Procedura obejmowała odparafinowanie, odzyskiwanie antygenów w wysokiej temperaturze, blokowanie niespecyficznych wiązań 2,5-procentową surowicą końską, inkubację z przeciwciałami pierwszorzędowymi w stężeniu 1:100 i detekcję sygnału. Wizualizację barwienia uzyskano, stosując jako chromogenu 3,3'-diaminobenzydyny. Tkanki wybarwiono hematoksyliną dla uwidocznienia jąder komórkowych. Preparaty zamknięto w automatycznej zaklejarce. Poziom immunoreaktywności białek oznaczono techniką morfometrii przy użyciu automatycznego analizatora obrazu i programu Image Pro Plus (Media Cybernetics) w 5 reprezentatywnych polach widzenia. Analiza obejmowała pole powierzchni reakcji immunologicznej i natężenie reakcji. Uśrednionym poziomem immunoreaktywności białka VEGF w tkance był iloczyn średniego pola powierzchni i średniego natężenia reakcji, wyrażony w jednostkach umownych (j.u.).

Dane zostały zapisane na dysku i analizowane w programie Statistica 6.0. Daneliczbowe przedstawione zostałyjako średnia +/-SD, z przedziałem reprezentatywności próby $95 \% \mathrm{Cl}$. Analizę statystyczną wzajemnych relacji badanych zmiennych przeprowadzono za pomocą testu Chi-kwadrat Kruskala-Wallisa i testu U Manna-Whitneya, a korelacje zachodzące pomiędzy zmiennymi oceniono testem Spearmana. Wyniki analizy o wartości $p<0,05$ uznano za znamienne statystycznie.

\section{Wyniki}

W ocenie klinicznej (klasyfikacja TNM, Childa-Pugha,

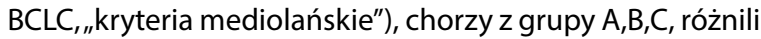
się $\mathrm{W}$ istotny sposób stopniem zaawansowania choroby nowotworowej, średnim poziomem AFP w surowicy krwi (Chisq $=6,2 ; p<0,04)$, liczbą płytek krwi (Chisq $=50,32$; $p<0,001)$ i wskaźnikiem INR Chisq $=31,13 ; p<0,001$ ).

W grupie chorych po resekcji wątroby (Grupa A) przeważały guzy o budowie litej, natomiast w grupach chorych po transplantacji (Grupa B) i chorych leczonych paliatywnie (Grupa C) — wariant beleczkowy guza (Chisq = 13,44; $p<0,001)$. Chorzy leczeni paliatywnie wyróżniali się większą liczbą inwazji nowotworu do naczyń mikrokrążenia (Chisq =9,43; $p<0,01)$. Pomiędzy grupami nie było różnic istotnych statystycznie w stopniu dojrzałości nowotworu (NS).

Średnią wartość odsetka endotelialnych komórek progenitorowych CD34+,309+ (EPCs) u 146 chorych z HCC uczestniczących w badaniu ustalono na 43,89\% CD34+, SD+/16,25 (41,23-46,5595\%Cl). OdsetekkomórekEPCsw Grupie A wynosił średnio 37,13\%, SD +/-12,64 (33,64-40,62 95\% Cl), w Grupie B 40,2\%, SD+/-12,57 (36,58-43,81 95\% Cl), w Grupie C - 56,16, SD+/-17,7 (50,09-61,38 95\% Cl); Chisq =30,55; $\mathrm{p}<0,001$.

Poziom koncentracji białka VEGF w tkance guza wynosił 77,69 j.u., SD+/-12,99 (63,82-96,4 95\% Cl) w Grupie A, 80,85 j.u., SD+/-13,11 (77,09-84,64 95\% Cl) w Grupie B, 87,08 j.u., SD +/-10,5 (83,89-90,28 95\% Cl) w Grupie C; Chisq $=9,67, p<0,008$ (ryc. 1).

Poziom koncentracji białka VEGF-R w tkance guza wynosił1 10,11 j.u., SD+/-59,11 (93,82-126,4 95\% Cl) w Grupie A 125,84 j.u., SD+/-48,29 (111,97-139,71 95\% Cl) w Grupie B, 161,69 j.u., SD +/-53,15 (145,53-177. $8595 \%$ Cl) w Grupie C; Chisq $=9,67 ; p<0,001$ (ryc. 2). 

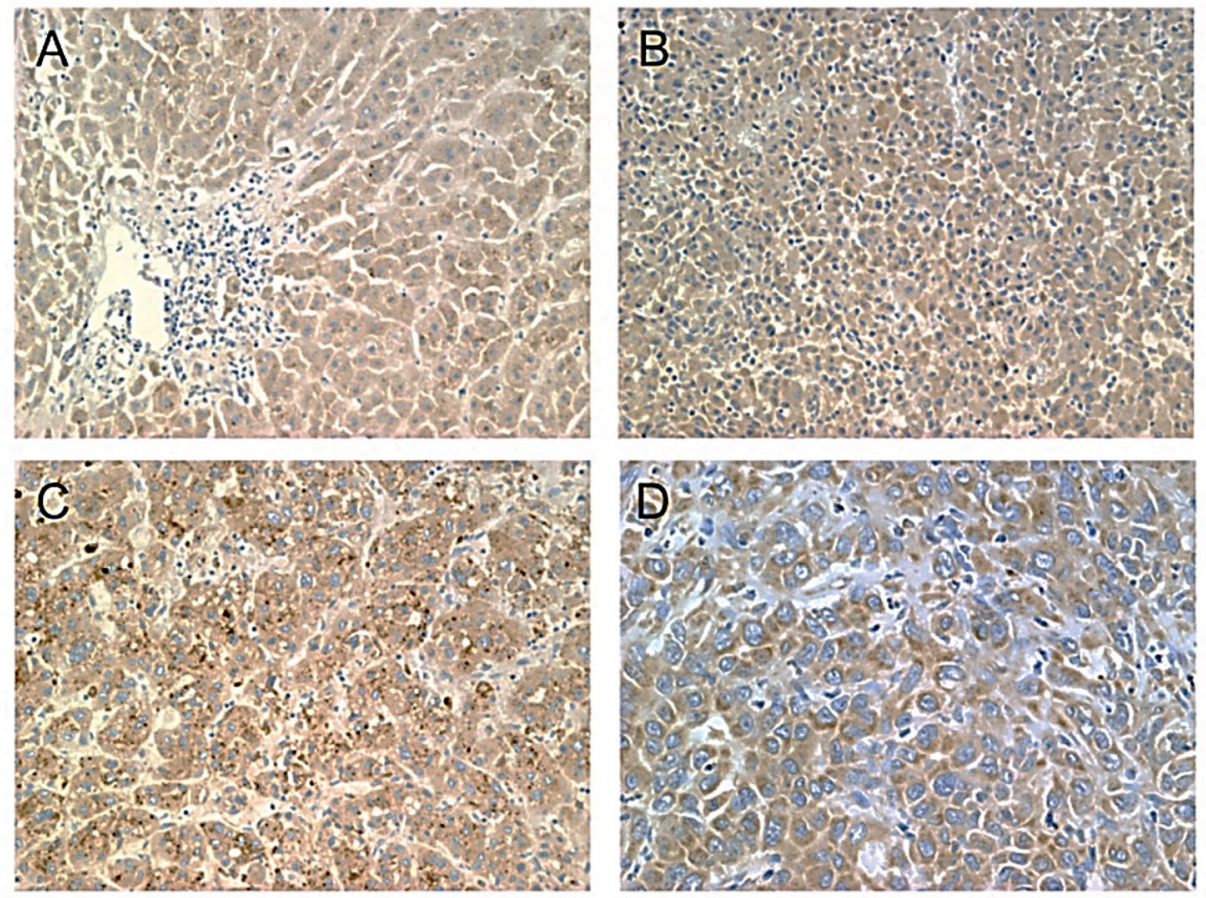

Rycina 1. Wynik barwienia immunohistochemicznego raka wątrobowokomórkowego na obecność VEGF. A - immunoreaktywność w prawidłowej wątrobie; B — słaba immunoreaktywności w komórkach HCC; C — średnio nasilona intensywność znakowania w komórkach HCC; D - obraz komórek raka powiększony 20 x, pokazujący znakowanie zlokalizowane w cytoplazmie; powiększenie A-C 10 x; D 20×
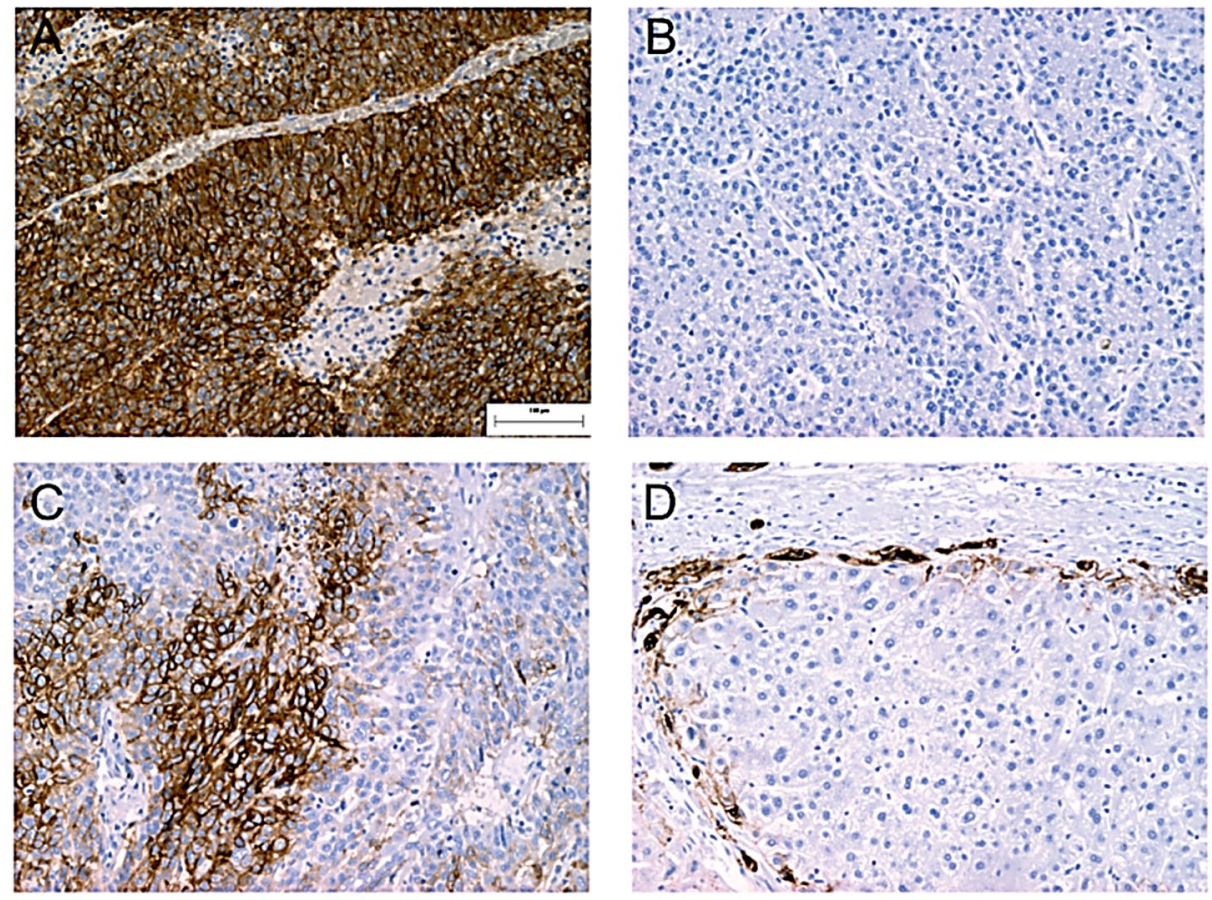

Rycina 2. Wynik znakowania immunohistochemicznego raka wątrobowokomórkowego na obecność EGFR. A — silna immunoreaktywność komórek raka; B — brak immunoreaktywności w komórkach HCC; C — średnio nasilona intensywność znakowania; D — znakowanie komórek raka położonych na obrzeżach gniazd nowotworowych. Skala $-100 \mu \mathrm{m}$ 
Tabela I. Wyniki badań czynników angiogenezy u 146 chorych z HCC ocenianych w programie

\begin{tabular}{|c|c|c|c|c|}
\hline $\begin{array}{l}\text { Czynniki } \\
\text { angiogenezy }\end{array}$ & $\begin{array}{c}\text { Grupa A } \\
\text { stopień klin. I - resekcja }\end{array}$ & $\begin{array}{c}\text { Grupa B } \\
\text { stopień klin. II - transplantacja }\end{array}$ & $\begin{array}{c}\text { Grupa C } \\
\text { stopień klin. III/IV - paliacja }\end{array}$ & Statystyka \\
\hline$\%$ EPCS & $\begin{array}{c}37,13 ; \mathrm{SD}+/-12,64 \\
(33,64-40,6295 \% \mathrm{Cl})\end{array}$ & $\begin{array}{c}40,2 ; \mathrm{SD}+/-12,57 \\
(36,58-43,8195 \% \mathrm{Cl})\end{array}$ & $\begin{array}{c}56,16 ; \mathrm{SD}+/-17,7 \\
(50,09-61,3895 \% \mathrm{Cl})\end{array}$ & $\begin{array}{c}\text { Chisq }=30,5 \\
p<0,001\end{array}$ \\
\hline $\begin{array}{l}\text { VEGF w guzie } \\
\text { (j.u. ) }\end{array}$ & $\begin{array}{c}77,69 ; S D+/-12,99 \\
(63,82-96,495 \% \mathrm{Cl})\end{array}$ & $\begin{array}{c}80,85 ; \mathrm{SD}+/-13,11 \\
(77,09-84,6495 \% \mathrm{Cl})\end{array}$ & $\begin{array}{c}87,08 ; \mathrm{SD}+/-10,5 \\
(83,89-90,2895 \% \mathrm{Cl})\end{array}$ & $\begin{array}{c}\text { Chisq }=9,67 \\
p<0,008\end{array}$ \\
\hline $\begin{array}{l}\text { VEGFR w guzie } \\
\text { (j.u. ) }\end{array}$ & $\begin{array}{c}110,11 ; S D+/-59,11 \\
(93,82-126,495 \% \mathrm{Cl})\end{array}$ & $\begin{array}{c}125,84 ; S D+/-48,29 \\
(111,97-139,7195 \% \mathrm{Cl})\end{array}$ & $\begin{array}{c}161,69 ; \mathrm{SD}+/-53,15 \\
(145,53-177,8595 \% \mathrm{Cl})\end{array}$ & $\begin{array}{c}\text { Chisq }=9,67 \\
p<0,001\end{array}$ \\
\hline $\begin{array}{l}\text { VEGF w surowicy } \\
(\mathrm{pg} / \mathrm{mL})\end{array}$ & $\begin{array}{c}352,56 ; S D+/-203,42 \\
(296,49-408,6395 \% \mathrm{Cl})\end{array}$ & $\begin{array}{c}317,46 ; \text { SD } 241,97 \\
(247,96-386,9695 \% \mathrm{Cl})\end{array}$ & $\begin{array}{c}319,64 ; \text { SD 333,18 } \\
(216,84-422,4695 \% \mathrm{Cl})\end{array}$ & NS \\
\hline
\end{tabular}

Poziom koncentracji białka VEGF w surowicy krwi wynosił średnio 352,56 pg/ml, SD+/-203,42 (296,49-408, 63 95\% Cl) w Grupie A, 317,46 pg/ml, SD 241,97 (247,96-386,9695\% Cl) w Grupie B, 319,64 pg/mL, SD 333, 18 (216,84-422,46 95\% Cl) w Grupie C; (N.S.).

Wariant budowy histologicznej guza, stopień dojrzałości i obecność naciekania przez guz naczyń mikrokrążenia nie wpływał w istotny sposób na różnice w poziomie czynników angiogenezy (NS).

\section{Dyskusja}

Naczyniowo-śródbłonkowy czynnik wzrostu VEGF wywiera bezpośredni lub pośredni wpływ na wiele czynników stymulujących proces angiogenezy [16, 17]. Interakcja pomiędzy VEGF i receptorami VEGFR prowadzi między innymi do mobilizacji ze szpiku kostnego endotelialnych komórek progenitorowych (EPCs), charakteryzujących się pozytywną reakcją z przeciwciałami różnicowania powierzchniowego CD34 i CD309. EPCs uczestniczą w budowie patologicznego ukrwienia rozwijającego się raka, a ich liczba we krwi obwodowej wzrasta wraz z rozwojem nowotworu [18]. Wieloośrodkowe badania wskazują, że oznaczenie ilościowe populacji EPCs we krwi obwodowej umożliwia rozpoznanie i ocenę stopnia zaawansowania HCC, ustalenie rokowania, a także monitorowanie przebiegu choroby i wyników jej leczenia [19-21]. W badaniu przedstawionym w pracy średnią wartość odsetka endotelialnych komórek progenitorowych (EPCs) we krwi obwodowej wszystkich chorych na HCC, których włączono do badania, ustalono na 43,89\% (SD+/-16,25; 41,23-46,55 95\% Cl) populacji komórek CD34+. Endotelialne komórki progenitorowe (EPCs) stanowiły nieliczną subpopulację komórek o fenotypie CD309+ pośród komórek hematopoetycznych CD45+i komórek śródbłonka naczyniowego CD45-. Stwierdzono istotne statystycznie różnice w odsetku EPCs pomiedzy chorymi zdatnymi do leczenia chirurgicznego i chorymi, których stan to leczenie wykluczał. Wyniki te wskazują jednoznacznie na wzrost potencjału angiogenezy guza w zależności od stopnia jego zaawansowania klinicznego i potwierdzają doświadczenia w tym zakresie wielu ośrodków na świecie [22-24].
W badaniu wykazano również zależność pomiędzy nadekspresją tkankową białek VEGF oraz VEGFR a klinicznym stopniem zaawansowania nowotworu. Prawidłowość ta zwraca uwagę badających zjawiska angiogenezy nowotworowej od czasu doniesień Misego w 1996 roku [12]. Dla określenia koncentracji czynnika VEGF i jego receptora w tkance HCC wykorzystano w pracy technikę immunohistochemii. W odróżnieniu od innych badań tego typu [6, 8, 21] do pomiaru poziomu immunoreaktywności badanych białek wykorzystano technikę morfometrii. Jej istotą jest densytometria przy użyciu automatycznego analizatora obrazu i programu Image Pro Plus (Media Cybernetics) i wyrażenie poziomu immunoreaktywności badanych białek w jednostkach umownych (j.u.). Tak określony poziom koncentracji VEGF i VEGFR wydaje się dużo bardziej precyzyjny i wiarygodny niż procentowe określenie komórek o pozytywnie wybarwionej cytoplaźmie, w arbitralnie wybranych polach widzenia $[2,6,10,21,25]$. Badania wykazały istotne statystycznie różnice pomiędzy badanymi grupami chorych, a także związek pomiędzy poziomem koncentracji białek VEGF i VEGFR w tkance guza i stopniem klinicznym zaawansowania choroby, ocenianym za pomocą standardowych systemów klasyfikacji. Poziom koncentracji białka VEGF w tkance guza odpowiada potencjałowi nowotworu do angiogenezy, a zatem do bardziej ekspansywnego rozwoju i większej złośliwości. Ogólnoustrojową emanacją expresji tkankowego VEGF, a zarazem przejawem jego oddziaływania jest zwiększona liczba endotelialnych komórek progenitorowych w krążeniu obwodowym. Powiązanie to, jak również związek ekspresji wymienionych czynników angiogenezy, wykazane zostało w omawianym badaniu.

Badanie nie wykazało natomiast istotnych statystycznie różnic w poziomie koncentracji naczyniowo-śródbłonkowego czynnika wzrostu VEGF w surowicy krwi, a także istotnej korelacji pomiedzy koncentracją VEGF w surowicy i pozostałymi zmiennymi. Poziom koncentracji VEGF wynosił średnio 329,88 pg/ml i był najwyższy u chorych z grupy A, tj. chorych ze zdrową lub wydolną wątrobą, a najniższy u chorych z grupy $\mathrm{B}, \mathrm{tj}$. chorych z marskością wątroby. W piśmiennictwie istnieją duże rozbieżności co do oceny 
wpływu białka VEGF na rozwój HCC. Podwyższony poziom koncentracji VEGF w surowicy krwi wydaje się być wczesnym etapem uogólnienia HCC, poprzedzającym rozsiew choroby i tworzenie się przerzutów odległych [2, 6-8, 20-22, 24-26]. Wykazano również korelację pomiedzy wysokim poziomem koncentracji czynnika VEGF w surowicy krwi i obecnością naciekania przez nowotwór naczyń mikrokrążenia [1, 21, $27,28]$. Złe rokowanie dotyczy zwłaszcza chorych z guzami charakteryzującymi się poziomem VEGF przekraczającymi $400 \mathrm{pg} / \mathrm{ml}$ i jednoczesnym wysokim poziomem ekspresji metaloproteinazy macierzy zewnątrzkomórkowej (Matrixmataloproteinaze - MMP-2, MMP-9). U wymienionych chorych stwierdzono zarówno zwiększoną liczbę nawrotów po radykalnym leczeniu chirurgicznym, jak i obniżenie całkowitej przeżywalności oraz czasu przeżywalności bez choroby [6, 23]. Przytoczone doświadczenia kontrastują z równie licznymi doniesieniami o niskich poziomach koncentracji czynnika VEGF u chorych z HCC, które nie odbiegają od wartości znajdowanych w surowicy krwi ludzi zdrowych. Tan i wsp. [26] nie stwierdzili istotnych statystycznie zależności pomiedzy poziomem koncentracji VEGF w surowicy krwi i charakterystyką patomorfologiczną guza u chorych z HCC leczonych przeszczepieniem wątroby. Poon i wsp. [20] określili średni poziom koncentracji VEGF w surowicy krwi u chorych na HCC na 269 pg/ml, przy czym nie udało im się wykazać znaczacego związku pomiędzy koncentracją VEGF i wieloma parametrami funkcji watroby oraz przebiegiem choroby. Nie znaleźli także istotnych różnic w poziomie czynnika VEGF w surowicy krwi chorych z nawrotem i chorych pozostających wolnymi od nowotworu po przebyciu radykalnego leczenia operacyjnego. W piśmiennictwie wymienia się różne przyczyny tak rozbieżnych ocen. Wpływ mogą mieć różnice rasowe wśród chorych z HCC — wyższe i powiązane z przejawami klinicznymi choroby poziomy koncentracji białka VEGF w surowicy krwi u chorych z Chin, a niższe i niepowiązane, u Japończyków czy przedstawicieli rasy kaukaskiej [8, 20, 25-28]. Znaczenie ma także czy rak rozwinął się $w$ wątrobie na tle zakażenia wirusem HBV, jak u większości chorych w Chinach, czy też na tle zakażenia HCV, przeważającego w krajach Zachodu $[25,26,28]$. Dowiedziono ponadto, że poziom białka VEGF w surowicy krwi zależy w istotny sposób od liczby płytek krwi $[7,8,20]$. Może być zatem wyższy u chorych mających guz w zdrowej, a przede wszystkim w wydolnej wątrobie, tj. zwykle kandydatów do resekcji wątroby, a niższy - u chorych z guzem i małopłytkowością w przebiegu marskości wątroby, tj. u chorych, u których z wyboru metodą leczenia chirurgicznego HCC jest transplantacja wątroby. Tak jak u chorych ocenianych w badaniu.

Rak wątrobowokomórkowy jest procesem ogólnoustrojowym, rozwijającym się w większości przypadków u chorych na marskość wątroby, zwłaszcza w marskości związanej z zakażeniem wirusami hepatotropowymi HBV/HCV. Na obecnym etapie wiedzy szansa wyleczenia istnieje tylko w przypadku guzów małych, dobrze zróżnicowanych i znajdujących się na wczesnym etapie rozwoju, tj. w I/II stopniu zaawansowania klinicznego. Stwarza ją jedynie leczenie chirurgiczne, resekcja lub transplantacja wątroby. Kandydaci wymagają starannej i właściwej oceny, którą przeprowadza się za pomocą standardowych, klinicznych systemów klasyfikacji BCLC, MELD, Childa-Pugha. Oznacza się zarazem stopień zaawansowania raka wg TNM, choć informacje te zostają zweryfikowane i dostępne są dopiero po badaniu patomorfologicznym. Pomimo starannie dobranych kryteriów i restrykcyjnego sposobu ich przestrzegania przy kwalifikacji chorych do leczenia resekcją lub transplantacją wątroby podawana w piśmiennictwie częstość nawrotów choroby przekracza 25-40\% (zależnie od statystyk) w ciągu pierwszych trzech lat od operacji $[3-5,8,20,21,27,28]$. Doświadczenia te skłaniają do poszukiwania dodatkowych kryteriów oceny, bazujących w znacznie większym stopniu niż obecnie na charakterystyce patomorfologicznej guza i jego właściwościach $[2,6,23]$. Jednym z kierunków są badania nad mechanizmami związanymi z procesem angiogenezy nowotworowej. Podwyższony poziom koncentracji naczyniowo-śródbłonkowego czynnika wzrostu (VEGF — Vascular Endothelial Growth Factor) i jego receptora (VEGFR) w tkance guza jest jednym z przejawów intensywnej angiogenezy i zwiększonej aktywności biologicznej nowotworu. Klinicznym wykładnikiem tej aktywności jest zwiększona liczba progenitorowych komórek nabłonka naczyniowego (EPCS — Endothelial Progenitor Cells) w krążeniu obwodowym, tym większa, im bardziej jest zaawansowany proces nowotworowy. Ocena obu czynników, tj. krążących we krwi obwodowej EPCs i badanie koncentracji tkankowego VEGF/VEGFR stanowi istotny oraz godny polecenia element całościowej oceny chorych w procesie kwalifikacji do leczenia chirurgicznego.

\section{Wnioski}

Oznaczenie krążących endotelialnych komórek progenitorowych (EPCs) oraz białka VEGF i VEGFR w tkance HCC świadczy o potencjale guza do angiogenezy i wskazuje na stopień zaawansowania raka. Oznaczenie czynników angiogenezy jest wartościowym uzupełnieniem klinicznej oceny chorych.

\section{Konflikt interesów: nie zgłoszono}

\section{Dr n. med. Janusz Sierdziński}

Zakład Informatyki Medycznej i Telemedycyny

Warszawski Uniwersytet Medyczny

ul. Banacha 1a, 02-097 Warszawa

e-mail:jsierdzinski@wum.edu.pl

\section{Piśmiennictwo}

1. Yang ZF, Poon RT. Vascular changes in hepatocellular carcinoma. Anat $\operatorname{Rec} 2008$; 291: 721-734.

2. Franchito A, Onori P, Renzi A i wsp. Expression of vascular endothelial growth factors and their receptors by hepatic progenitor cells in human liver diseases. Hepatobiliary Surg Nutrit 2013; 2: 68-77. 
3. Zhu K, Dai Z, Zhou J. Biomarkers for hepatocellular carcinoma: progression in early diagnosis, prognosis, and personalized therapy. Biomark Res 2013; 1: 1-10.

4. Fan ST, Yang ZF, Ho DW i wsp. Prediction of posthepatectomy recurrence of hepatocellular carcinoma by circulating stem cells a prospective study. Ann Surg 2011; 254: 569-576.

5. Chan EY, Larson AM, Fix OK i wsp. Identifying risk for recurrent hepatocellular carcinoma after liver transplantation: implications for surveillance studies and new adjuvant therapies. Liver Transp/ 2008; 14: 956-965.

6. Yegin EG, Siykhymbayev A, Eren F i wsp. Prognostic implication of serum vascular endothelial growth factor in advanced hepatocellular carcinoma staging. Ann Hepatol 2013; 12: 915-925.

7. Yu D, Chen J, Sun T i wsp. Mechanism of endothelial progenitor cell recruitment into neo-vessels in adjacent non-tumor tissues in hepatocellular carcinoma. BMC Cancer, 2010; 10: 435-445.

8. Shim JH, Park JW, Kim JH i wsp. Association between increment of serum VEGF level and prognosis after transcatheter arterial chemoembolization in hepatocellular carcinoma patients. Cancer Sci 2008; 99: 2037-2044.

9. Mise $\mathrm{M}$, Arii $\mathrm{H}$, Higashituji $\mathrm{H}$ i wsp. Clinical significance of vascular endothelial growth factor and basic fibroblast growth factor gene expression in liver tumor. Hepatology 1996; 23: 455-464.

10. Mathonnet $M$, Descottes $B$, Valleix D i wsp. VEGF in hepatocellular carcinoma and surrounding cirrhotic liver tissue. World J Gastroenterol 2006; 12: 830-831.

11. Kaseb A, Hanbali A, Cotant M i wsp. Vascular endothelial growth factor in the management of hepatocellular carcinoma: a review of literature. Cancer 2009; 115: 4895-4906.

12. Villanueva A, Llovet JM. Targeted therapies for hepatocellular carcinoma. Gastroenterology 2011; 140: 1410-1426.

13. Otto W, Król M, Maciaszczyk M i wsp. Identification and significance of circulating endothelial progenitor cells in patients with hepatocellular carcinoma. Nowotwory J Oncol 2013; 5: 383-394.

14. Otto W, Król M, Wilkowojska U i wsp. Tumor grading, architectural growth pattern and angiogenesis proprieties correlation in surgical patients treated for HCC. Int J Surg Res Pract 2014; 1: 2-12.

15. Otto W, Król M, Maciaszczyk M i wsp. Levels and values of circulating hematopoietic and endothelial progenitor cells in patients with hepatocellular carcinoma. J Liver 2014; 3: 4-14.
16. Zhu H, Shao Q, Sun X i wsp. The mobilization, recruitment and contribution of bone marrow-derived endothelial progenitor cells to the tumor neovascularization occur at an early stage and throughout the entire process of hepatocellular carcinoma growth. Oncol Rep 2012; 28: 1217-1224.

17. Zhu AX, Duda DG, Sahani DV i wsp. HCC and angiogenesis: possible targets and future direction. Nat Rev Clin Oncol 2011; 8: 292-301.

18. Yu D, Chen J, Sun X i wsp. Mechanism of endothelial progenitor cell recruitment into neo-vessels in adjacent non-tumor tissues in hepatocellular carcinoma. BMC Cancer 2010; 10: 435-445.

19. Sun XT, Yuan XW, Zhu HT i wsp. Endothelial precursor cells promote angiogenesis in hepatocellular carcinoma. World J Gastroenterol 2012; 18: 4925-4933.

20. Poon RT, Ng IO, Lau C i wsp. Serum vascular endothelial growth factor predicts venous invasion in hepatocellular carcinoma: a prospective study. Annals Surg 2001; 233: 227-235.

21. Chen $\mathrm{CH}, \mathrm{Chang} \mathrm{LT}$, Tung WC i wsp. Levels and values of circulating endothelial progenitor cells, soluble angiogenic factors, and mononuclear cell apoptosis in liver cirrhosis patients. J Biomed Sci 2012; 19: 66-77.

22. Fadini GP, Baesso I, Albiero M i wsp. Technical notes on endothelial progenitor cells: ways to escape from the knowledge plateau. Atherosclerosis 2008; 197: 496-503.

23. Oishi N, Wang XW. Novel therapeutic strategies for targeting liver cancer stem cells. Int J Biol Sci 2011; 7: 517-535.

24. Beerepoot LV, Mehra N, Vermaat JS i wsp. Increased levels of viable circulating endothelial cells are an indicator of progressive disease in cancer patients. Ann Oncol 2004; 15: 139-145.

25. Tan A, Kim R, El-Gazzaz G i wsp. Serum vascular endothelial growth factor level in patients with hepatocellular carcinoma undergoing liver transplantation: experience of a single Western Center. Int J Org Transplant Med 2012; 3: 42-51.

26. Guo RP, Zhong C, Shi M i wsp. Clinical value of apoptosis and angiogenesis factors estimating the prognosis of hepatocellular carcinoma. J Cancer Res Clin Oncol 2006; 132: 457-555.

27. Kanematsu M, Osada S, Amaoka N i wsp. Expression of vascular endothelial growth factor in hepatocellular carcinoma and the surrounding liver and correlation with MRI findings. AJR 2005;184: 832-841.

28. Kwak BK, Shim HJ, Park ES i wsp. Hepatocellular carcinoma: correlation between vascular endothelial growth factor level and degree of enhancement by multiphase contrast enhanced computed tomography. Invest Radiol 2001; 36: 487-492. 